\title{
Electron impact mass spectrometry of some thienopyrimidone derivatives
}

\author{
Renata C. de Oliveira ${ }^{\mathrm{a}, \mathrm{b}}$, Antonio C.C. Freitas ${ }^{\mathrm{b}}$ and José G. de Lima ${ }^{\mathrm{b}, *}$ \\ ${ }^{a}$ Laboratório de Química Medicinal e Ensaios Farmacológicos (LQMEF), Faculdade de Farmácia, \\ UFF, Rio de Janeiro, Brasil \\ ${ }^{\mathrm{b}}$ Departamento de Fármacos, Faculdade de Farmácia, UFRJ, Ilha do Fundão, 21944-910, \\ Rio de Janeiro, Brasil
}

Abstract. The electron impact mass spectra of some previously synthesized thienopyrimidones have been recorded and the identity of various ions in the mass spectra established.

\section{Introduction}

Many thienopyrimidone derivatives show diverse pharmacological activities including antibacterial/antiviral [1-3], analgesic/antiinflamatory [4-6] and antiallergic activities [7]. Our interest in the synthesis, biological and spectroscopic properties of heterocyclic compounds [8,9], prompted us to investigate the electron impact mass spectra of some thienopyrimidones previously prepared in our laboratories $[10,11]$ (Table 1).

Table 1

Thienopyrimidone derivatives<smiles>Cc1nc2sc3c(c2c(=O)n1/N=C/[In])CCCC3</smiles>

\begin{tabular}{cccc}
\hline Compounds & $\mathrm{Ar}$ & Formula & $\mathrm{M}$ \\
\hline I & $\mathrm{C}_{6} \mathrm{H}_{5}$ & $\mathrm{C}_{18} \mathrm{H}_{17} \mathrm{~N}_{3} \mathrm{OS}$ & 323 \\
II & $p-\mathrm{CH}_{3}-\mathrm{C}_{6} \mathrm{H}_{4}$ & $\mathrm{C}_{19} \mathrm{H}_{19} \mathrm{~N}_{3} \mathrm{OS}$ & 337 \\
III & $p-\mathrm{OH}-\mathrm{C}_{6} \mathrm{H}_{4}$ & $\mathrm{C}_{18} \mathrm{H}_{17} \mathrm{~N}_{3} \mathrm{O}_{2} \mathrm{~S}$ & 339 \\
IV & $p-\mathrm{F}-\mathrm{C}_{6} \mathrm{H}_{4}$ & $\mathrm{C}_{18} \mathrm{H}_{16} \mathrm{FN}_{3} \mathrm{OS}$ & 341 \\
V & $p-\mathrm{Cl}-\mathrm{C}_{6} \mathrm{H}_{4}$ & $\mathrm{C}_{18} \mathrm{H}_{16} \mathrm{ClN}_{3} \mathrm{OS}$ & 357 \\
VI & $p-\mathrm{NO}_{2}-\mathrm{C}_{6} \mathrm{H}_{4}$ & $\mathrm{C}_{18} \mathrm{H}_{16} \mathrm{~N}_{4} \mathrm{O}_{3} \mathrm{~S}$ & 368 \\
VII & $\mathrm{C}_{10} \mathrm{H}_{7}$ & $\mathrm{C}_{22} \mathrm{H}_{19} \mathrm{~N}_{3} \mathrm{OS}$ & 383 \\
\hline
\end{tabular}

\footnotetext{
*Corresponding author. E-mail: gildo@ pharma.ufrj.br.
} 


\section{Results and discussion}

Principal peaks in the EI mass spectra of the compounds I-VII are presented in Tables 2 and 3. The isotopic fragment $\mathrm{M}+2$ denote the presence of sulfur atom in all the compounds and chlorine atom for the compound $\mathbf{V}$, and are in agreement with the proposed structures.

The main features of the spectra from molecular ions are summarized in Scheme 1. In this series of compounds there are two possibilities to form the base peak at $m / z=220$ from molecular ions either by loss of a neutral molecule $\operatorname{ArCN}$ due to cleavage of a bond $\alpha$ to the $\mathrm{N}=\mathrm{C}$ double bond or by subsequent elimination of aryl and nitrile radicals. In both cases an hydrogen atom migration occurs. The high stability of the base peak probably arises from a prototropic rearrangement in the pyrimidine ring as shown below:<smiles>Cc1nc2sc3c(c2c(=O)[nH]1)CCCC3</smiles>

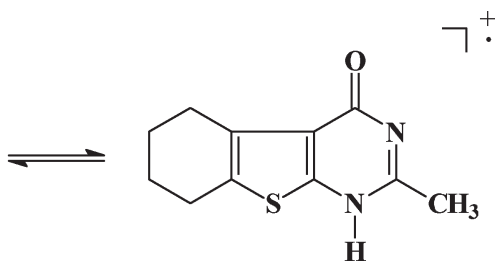

Other important peaks arising from molecular ions are those represented by A, B and C fragments. Formation of these fragments involves an $\alpha$-cleavage of the $\mathrm{N}=\mathrm{C}$ double bond yielding $\mathrm{A}$ and $\mathrm{B}$. A rup-

Table 2

Principal fragments and intensities from molecular ions

\begin{tabular}{|c|c|c|c|c|c|c|}
\hline \multirow[t]{2}{*}{ Compounds } & \multirow[t]{2}{*}{$\mathrm{M}^{+}$} & \multicolumn{2}{|c|}{$m / z(\%)$} & \multirow[t]{2}{*}{ A } & \multirow[t]{2}{*}{ B } & \multirow[t]{2}{*}{$\mathrm{C}$} \\
\hline & & 246 & 220 & & & \\
\hline I & $323(40)$ & 4 & 100 & 77 (37) & $103(114)$ & $90(17)$ \\
\hline II & 337 (16) & 2 & 100 & $91(27)$ & $117(7)$ & $104(22)$ \\
\hline III & 339 (17) & 1 & 100 & $93(6)$ & $119(7)$ & $106(15)$ \\
\hline IV & $341(40)$ & 3 & 100 & $95(37)$ & $121(15)$ & $108(31)$ \\
\hline $\mathbf{V}$ & 357 (41) & 3 & 100 & 111 (19) & 137 (7) & 124 (13) \\
\hline VI & $368(37)$ & 4 & 100 & $122(12)$ & $148(5)$ & 135 (22) \\
\hline VII & $373(23)$ & 2 & 100 & $127(34)$ & $153(25)$ & $140(12)$ \\
\hline
\end{tabular}

Table 3

Principal fragments and intensities from the base peak

\begin{tabular}{cccrrrrrrr}
\hline Compounds & \multicolumn{7}{c}{$m / z(\%)$} \\
\cline { 2 - 10 } & 205 & 192 & 177 & 164 & 149 & 136 & 108 & 104 & 76 \\
\hline I & 17 & 74 & 14 & 6 & 5 & 3 & 5 & 12 & 7 \\
II & 18 & 83 & 3 & 6 & 5 & 4 & 6 & 22 & 4 \\
III & 17 & 73 & 3 & 11 & 5 & 7 & 5 & 15 & 13 \\
IV & 20 & 83 & 20 & 10 & 2 & 5 & 32 & 3 & 4 \\
V & 15 & 72 & 17 & 9 & 7 & 4 & 5 & 2 & 6 \\
VI & 22 & 93 & 32 & 22 & 16 & 9 & 1 & 6 & 16 \\
VII & 13 & 57 & 6 & 5 & 3 & 3 & 3 & 1 & 3 \\
\hline
\end{tabular}




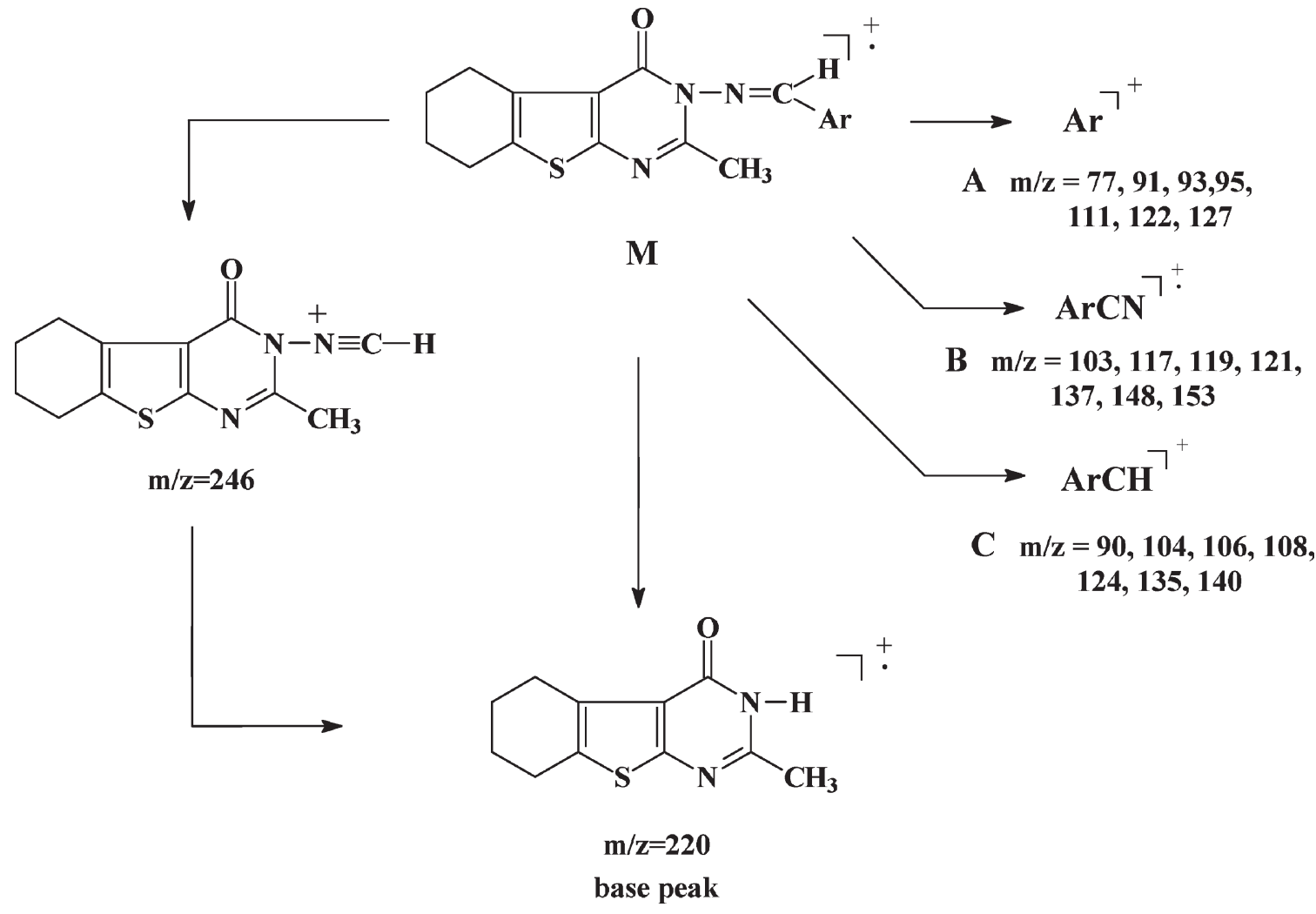

Scheme 1.

ture from $\mathrm{N}=\mathrm{C}$ double bond itself accounting for the $\mathrm{C}$ fragment. All of the compounds also show the ion $m / z=246$ though of very low intensity.

The main ions formed from the base peak are obtained from four possible pathways with similar fragmentation pattern nearly always with loss of a neutral molecule.

Although paths 1 and 2 in Scheme 2 show the same peaks at $m / z=192, m / z=164$ and $m / z=136$, they are structurally different. Basically, in two paths the different losses of 28 mass units correspond to the same way of elimination of the neutral molecules $\mathrm{CO}, \mathrm{C}_{2} \mathrm{H}_{4}$ and $\mathrm{N}_{2}$. Thus, through path 1 the ion at $m / z=192$ can be formed from the base peak by loss of ethene molecule. A further elimination of carbone monoxide leads to the ion at $m / z=164$. This ion by loss of $\mathrm{C}_{2} \mathrm{H}_{4}$ moiety yields the ion at $m / z=136$ which then eliminates a nitrogen molecule to afford the ion at $m / z=108$.

On the other hand, through path 2, the same peaks are obtained by the successive loss of the neutral molecules $\mathrm{CO}$ [12], $\mathrm{C}_{2} \mathrm{H}_{4}, \mathrm{~N}_{2}$ and $\mathrm{C}_{2} \mathrm{H}_{4}$. The presence of an ion at $m / z=104$ is a result of the loss of a sulfur atom.

In path 3 the base peak loses 15 mass units which corresponds to the loss of a $\mathrm{NH}$ fragment to give the ion at $m / z=205$. This ion by two subsequent eliminations of 28 mass units $\left(\mathrm{CO}\right.$ and/or $\left.\mathrm{C}_{2} \mathrm{H}_{4}\right)$ must give the peaks at $m / z=177$ and $m / z=149$. Or else, the former can be formed through path 4 by direct loss of neutral molecule HNCO [12] from the base peak. Beside, this ion can give the same fragment at $m / z=136$ (path 2) by loss of an acetonitrile molecule. A similar fragmentation from ion at $m / z=149$ affords a peak at $m / z=108$ wich can form the ion of $m / z=76$ by loss a sulfur atom. 


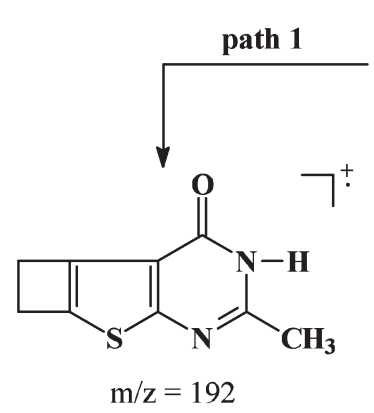<smiles>Cc1nc2sc3c(c2c(=O)[nH]1)CCCC3</smiles><smiles>CC1=Nc2sc3c(c2C1=O)CCCC3</smiles>
$\mathrm{m} / \mathrm{z}=205$<smiles>C1CCCCCC1</smiles><smiles>CC1=Nc2sc3c(c21)CCCC3</smiles><smiles>Cc1nc2sc3c(c2[nH]1)CC3</smiles>

$\mathrm{m} / \mathrm{z}=164$

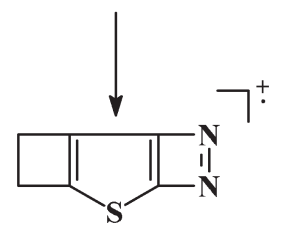

$\mathrm{m} / \mathrm{z}=136$<smiles>[3H]C1=Nc2sc3c(c21)CCCC3</smiles>

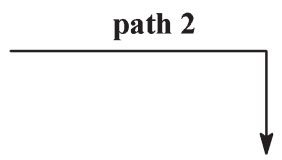<smiles>[3H][I-]n1c(C)nc2sc3c(c21)CCCC3</smiles>

path 4

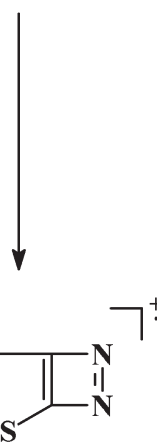

$\mathrm{m} / \mathrm{z}=164$

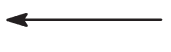<smiles>[3H]C1C=CC2=C1CCCC2</smiles>

$\mathrm{m} / \mathrm{z}=104$
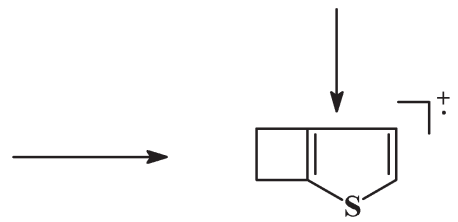

$\mathrm{m} / \mathrm{z}=108$

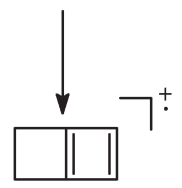

$\mathrm{m} / \mathrm{z}=76$

Scheme 2 .

\section{Experimental}

Electron impact mass spectra were recorded using a VG Autospec Q instrument operating at $70 \mathrm{eV}$ ionizing energy. Samples were introduced by using a direct inlet system with a source temperature of $180^{\circ} \mathrm{C}$. 


\section{Conclusion}

The fragmentation pathways for thienopyrimidones studied show the principal characteristic such as the same base peak at $m / z=220$ for all the compounds, a common fragmentation pattern with an elimination of neutral molecules $\mathrm{CO}, \mathrm{C}_{2} \mathrm{H}_{4}, \mathrm{~N}_{2}, \mathrm{CH}_{3} \mathrm{CN}$ and, finally, the $\mathrm{M}+2$ isotope peak mainly due to the presence of sulfur atom.

\section{Acknowledgements}

We thank the CNPq (Conselho Nacional de Desenvolvimento Científico e Tecnológico, Brasil) for financial support. We would also like to thank the Analytical Central of NPPN-UFRJ for the mass spectra.

\section{References}

[1] M.A. El-Sherbenyl, M.B. El-Ashmawy, H.I. El-Subbagh, A.A. El-Eman and F.A. Badria, Eur. J. Med. Chem. 30 (1995), 445.

[2] M.M. Ghorab and S.G.A. Hamide, Phosphorus, Sulfur, Silicon Relat. Elem. 106 (1995), 9.

[3] Z.A. Hozien, F.M. Atta, Kh.M. Hassan, A.A. Abdel-Wahab and S.A. Ahmed, Synth. Commun. 26 (1996), 3733.

[4] M.S. Mahans, S.D. Sharma and S.G. Amin, J. Med. Chem. 15 (1972), 106.

[5] M. Perrissin, M. Favre, C. Luu-Duc, F. Huguet, C. Gaultier and G. Narcisse, Eur. J. Med. Chem. 23 (1988), 453.

[6] M.B. Devani, C.J. Shishoo, U.S. Pathak, S.H. Parikh, G.F. Shah and A.C. Padhya, J. Pharm. Sci. 65 (1976), 660.

[7] D.L. Temple, J.P. Yevich, R.R. Convington, C.A. Hanning, R.J. Seidehamel, H.K. Mackey and M.J. Bartek, J. Med. Chem. 22 (1979), 505.

[8] S.J. de Melo, J.G. de Lima, S.L. Galdino, I.R. Pitta and C. Luu-Duc, Spectros. Int. J. 8 (1990), 269.

[9] J.G. de Lima, M. Perrissin, J. Chantegreland and C. Luu-Duc, Spectros. Int. J. 11 (1993), 45.

[10] H.P. Morin, R.C. de Oliveira, A.C.C. Freitas and J.G. de Lima, in: Abstracts 19th RSBQ, Braz. Chem. Soc., 1996, QO-059.

[11] R.C. de Oliveira, A.C.C. Freitas, E.C.P.A. Ximenes and J.G. de Lima, J. Pharm. Belg. 52 (1997), 213.

[12] U.S. Pathak, S. Singh and J. Padth, Ind. J. Chem. 30B (1991), 618. 


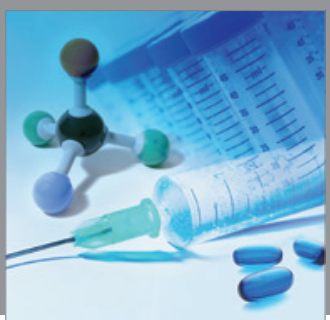

International Journal of

Medicinal Chemistry

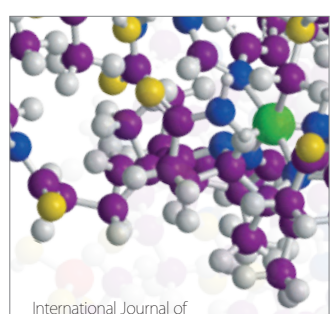

Carbohydrate Chemistry

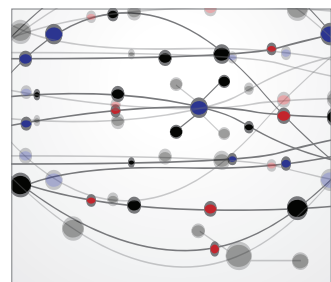

The Scientific World Journal
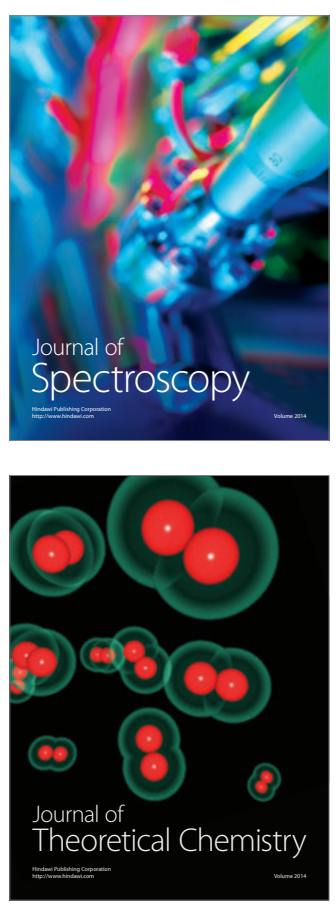
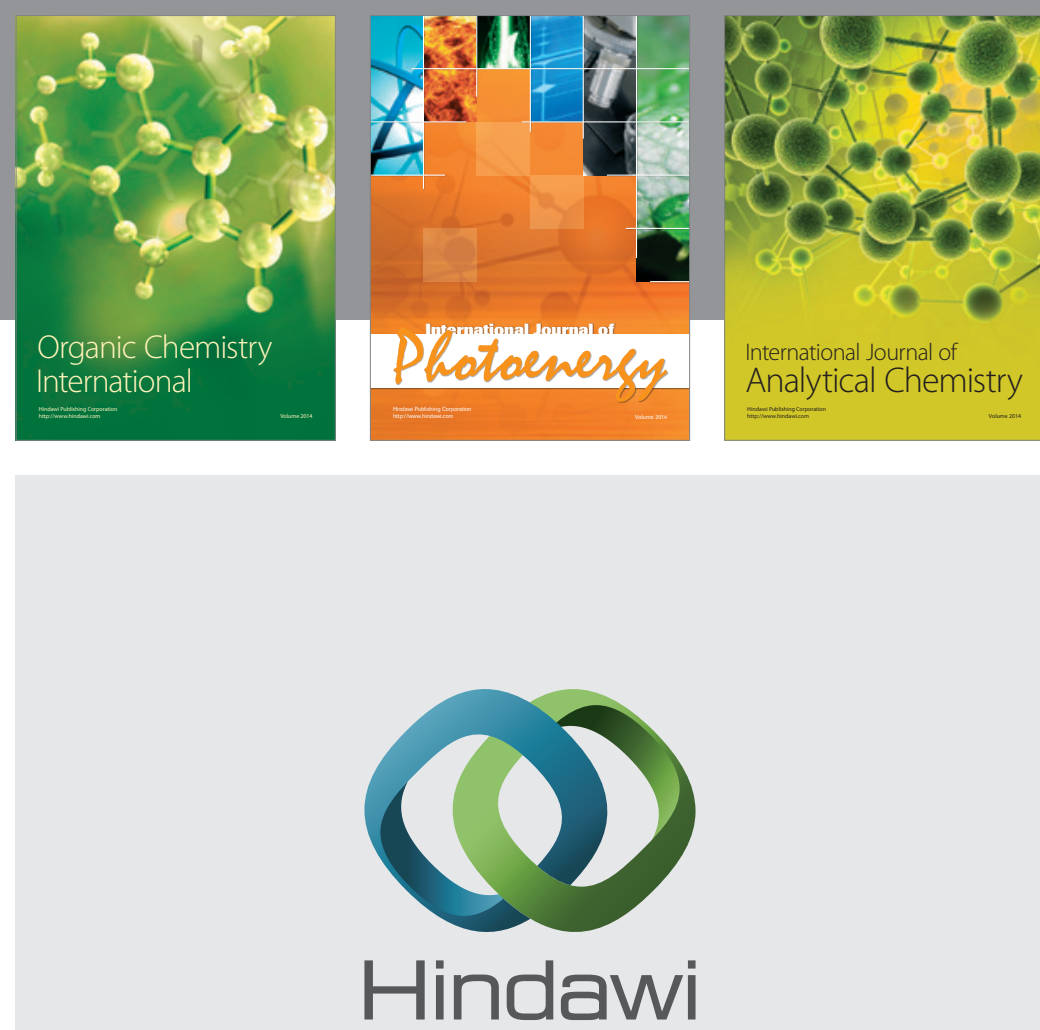

Submit your manuscripts at

http://www.hindawi.com
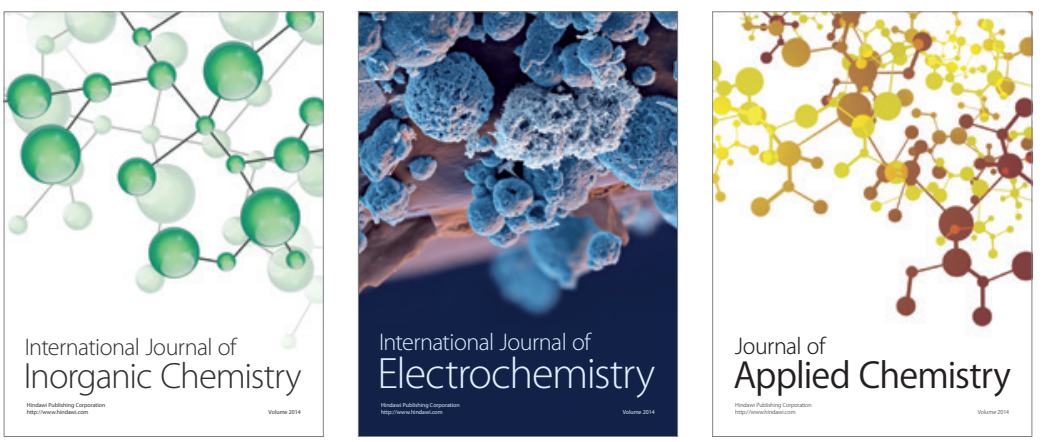

Journal of

Applied Chemistry
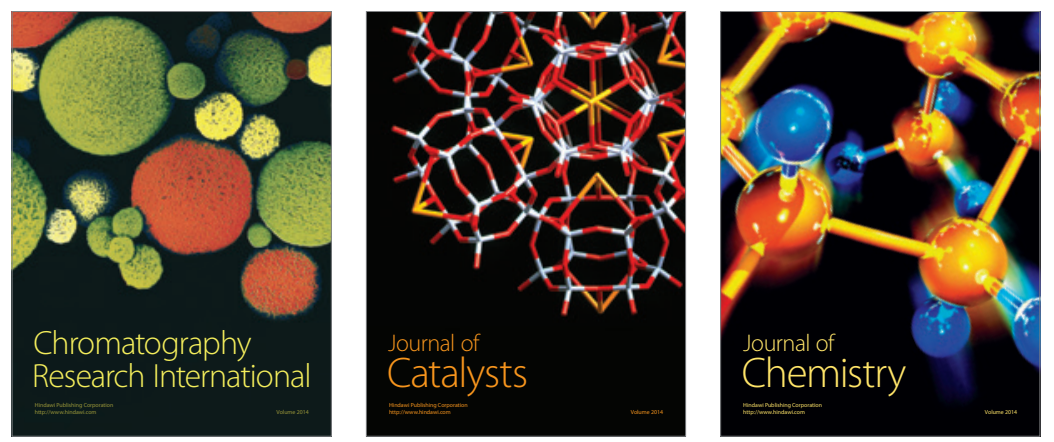
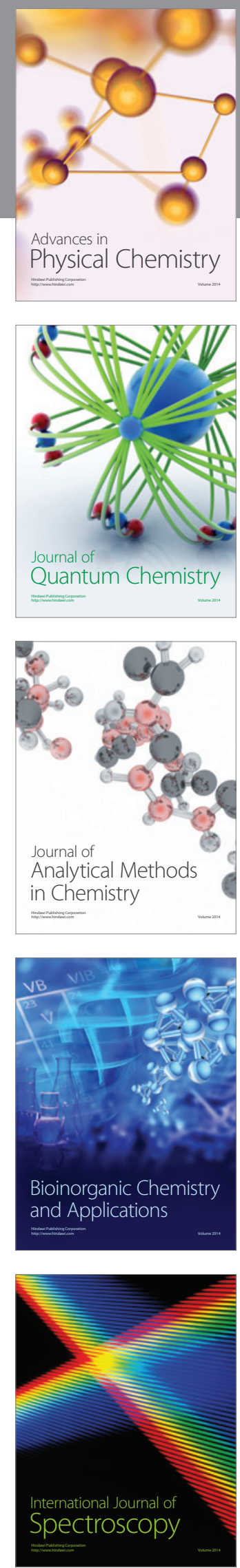